\title{
Implementation of Quality by Design for the Development and Validation of Pioglitazone Hydrochloride by RP-UPLC with Application to Formulated Forms
}

\author{
Cijo M. Xavier and Kanakapura Basavaiah \\ Department of Studies in Chemistry, University of Mysore, Manasagangotri, Mysore, Karnataka 570006, India \\ Correspondence should be addressed to Kanakapura Basavaiah, basavaiahk@yahoo.co.in
}

Received 30 September 2012; Accepted 6 November 2012

Academic Editors: E. Boselli, M. C. Bruzzoniti, B. Carbonnier, A. Sanches Silva, and S. Valsecchi

Copyright ( 2012 C. M. Xavier and K. Basavaiah. This is an open access article distributed under the Creative Commons Attribution License, which permits unrestricted use, distribution, and reproduction in any medium, provided the original work is properly cited.

\begin{abstract}
Quality by Design (QbD) is a philosophy that refines the level of knowledge associated with a product that uses process understanding to deliver a product with the desired critical quality attributes. The objective of this study was to develop an integrated multivariate QbD approach to develop and quantify the constituent concentrations of pioglitazone hydrochloride (PGZ) drug in its pure and formulated forms. To facilitate studies investigating the determination of PGZ in bulk drug and its pharmaceutical formulations, a rapid UPLC method was developed and validated for the determination of PGZ accompanied by its degradation studies in different stress conditions. The method fulfilled validation criteria and was shown to be sensitive, with limits of detection (LOD) and quantitation (LOQ) of 0.01 and $0.05 \mu \mathrm{g} \mathrm{mL}{ }^{-1}$, respectively. The percent relative standard deviations for robustness and ruggedness were observed within the range of $0.1-1.74$. The calibration graph was linear in the range of $0.05-$ $300 \mu \mathrm{g} \mathrm{mL}{ }^{-1}$. The applicability of the method was shown by analysis of formulated drug samples and spiked human urine. The proposed method can be used for routine analysis in quality controlled laboratories for its bulk and formulated product and this is the first reported UPLC method for the assay of PGZ.
\end{abstract}

\section{Introduction}

Quality by design is a systematic approach to development that begins with predefined objectives and emphasizes product and process understanding and process control, based on sound science and quality risk management $[1,2]$. The objective of the QbD initiative is to demonstrate both understanding and control of pharmaceutical processes to deliver high quality pharmaceutical products while affording opportunities for continuous improvement. QbD delivers a better understanding of method capabilities and limitations and ensures a superior chance of successful downstream method validation and transfer. It has become an important paradigm in the pharmaceutical industry since its introduction by the US Food and Drug Administration [3-7]. The QbD concept can be extended to analytical methods [815]. The analytical methods used for the analysis of active pharmaceutical ingredients (API) and drug products are an integral part of the QbD.

Pioglitazone (PGZ), chemically known as [( \pm )-5-[[4-[2(5-ethyl-2-pyridinyl) ethoxy] phenyl] methyl]-2,4-] thiazolidinedione monohydrochloride (Figure 1) is an oral antihyperglycemic [16] agent used for the action to treat diabetes. It belongs to thiazolidinediones (TZDs), also known as glitazones, which are a relatively new class of oral hypoglycemic, insulin-sensitizing drugs that are used clinically as thirdlineagents in the management of diabetes mellitus type 2 as they help restore peripheral insulin sensitivity. TZDs activate peroxisome proliferator-activated receptor gamma $(\operatorname{PPAR}-\gamma)$, a nuclear receptor that regulates the production of proteins involved in glucose and lipid homeostasis, and, to a lesser extent, PPAR- $\gamma$ [17]. It increases systemic insulin sensitivity in tissues of animal models and humans with type 2 diabetes and the metabolic syndrome [18]. 


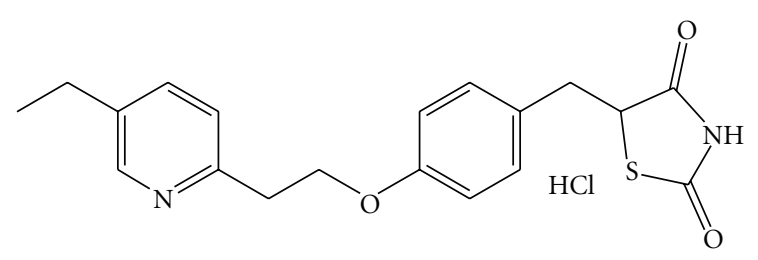

FIGURE 1: Structure of pioglitazone $\mathrm{HCl}$.

PGZ is included in the United States Pharmacopoeia [19] and official drafts of European Pharmacopoeia [20], both recommend HPLC method for its assay. In the literature, several HPLC methods [21-28, 30-37], [29] are available for the determination of PGZ in, dosage forms [21-31], urine [32], plasma [33-35], and related substances [36]. Reported methods for the determination of PGZ in pharmaceuticals include HPTLC [38], spectrophotometry [39-41], electrochemical [42], and mass spectra [43].

According to literature survey, there are quite a few publications on UPLC method development $[44,45]$ strategy. The reported UPLC methods for the determination of PGZ are for combination drugs only $[46,47]$. Method development approach with RP-UPLC specifically focused on pharmaceutical development in a $\mathrm{QbD}$ environment for PGZ has not been reported anywhere. Therefore, there is an unmet need to investigate a systematic UPLC method development approach for pharmaceutical development using QbD principles to ensure the quality of the method throughout the product lifecycle.

The primary objective of this study was to implement QbD approach to develop and validate an RP-UPLC method that could separate drug in the bulk and formulated forms from its potential related substances and to establish an indepth understanding of the method and build in the quality during the method development to ensure optimum method performance over the lifetime of the product with a suitable degradation data.

\section{Methods}

2.1. Materials and Reagents. Pure active ingredient sample of PGZ was kindly supplied by Glenmark Pharmaceuticals, Mumbai, India, as gift. PGZ-containing tablets; Neoglit30 (30 mg) (Novus Life Sciences Private Limited, Mumbai), Oglo-15 (15 mg) (Panacea biotec, Mumbai) were procured from the local market. HPLC grade acetonitrile was purchased from Merck, potassium dihydrogenorthophosphate, triethylamine and orthophosphoricacid were from Qualigens-India. Doubly distilled water was used throughout the investigation.

2.2. Chromatographic Conditions and Equipments. Analyses were carried out on a Waters Aquity UPLC with Tunable UV (TUV) detector. The output signal was monitored and processed using Empower software. The chromatographic column used was Acquity UPLC BEH C-18 $(100 \times 2.1) \mathrm{mm}$ and $1.7 \mu \mathrm{m}$ particle size. Isocratic elution process was adopted throughout the analysis. Mobile phase used was 20:80 (acetonitrile : buffer) v/v (buffer-2.2 g. potassium dihydrogen orthophosphate in 1 litre water and $1 \mathrm{~mL}$ triethylamine, then adjusted the $\mathrm{pH}$ to 3.2 with diluted o-phosphoric acid).

2.3. Instrumental Parameters. The isocratic flow rate of mobile phase was maintained at $0.20 \mathrm{~mL} \mathrm{~min}^{-1}$. The column temperature was adjusted to $25^{\circ} \mathrm{C}$. The injection volume was $2 \mu \mathrm{L}$. Eluted sample was monitored at $220 \mathrm{~nm}$ and the run time was $5.0 \mathrm{~min}$. The retention time of the sample was about $2.1 \mathrm{~min}$.

2.4. Stress Study. All stress decomposition studies were performed at an initial drug concentration of $200 \mu \mathrm{g} \mathrm{mL}-1$ in mobile phase. Acid hydrolysis was performed in $1 \mathrm{M}$ $\mathrm{HCl}$ at $80^{\circ} \mathrm{C}$ for $2 \mathrm{~h}$. The study in alkaline condition was carried out in $1.0 \mathrm{M} \mathrm{NaOH}$ at $80^{\circ} \mathrm{C}$ for $3 \mathrm{~h}$. The study in neutral condition was carried out in water at $80^{\circ} \mathrm{C}$ for $3 \mathrm{~h}$. Oxidative studies were carried out at $80^{\circ} \mathrm{C}$ and $5 \%$ hydrogen peroxide for $2 \mathrm{~h}$. For photolytic degradation studies, pure drug in solid state was exposed to 1.2 million lux hours in a photo stability chamber [48]. Additionally, the drug powder was exposed to dry heat at $105^{\circ} \mathrm{C}$ for $2 \mathrm{~h}$. Samples were withdrawn at appropriate time and subjected to UPLC analysis after suitable neutralisation and dilution.

2.5. Preparation of Stock Solution. A stock standard solution of PGZ $\left(1000 \mu \mathrm{g} \mathrm{mL}^{-1}\right)$ was prepared in mobile phase and used for validation.

\subsection{Procedures}

2.6.1. Procedure for Preparation of Calibration Curve. Working solutions containing $0.05-300 \mu \mathrm{g} \mathrm{mL}^{-1}$ PGZ were prepared by serial dilutions of aliquots of the stock solution. Aliquots of $2 \mu \mathrm{L}$ were injected (six injections) and eluted with the mobile phase under the reported chromatographic conditions. The average peak area versus the concentration of PGZ in $\mu \mathrm{g} \mathrm{mL}^{-1}$ was plotted. Alternatively, the corresponding regression equation was derived using mean peak areaconcentration data and the concentration of the unknown was computed from the regression equation.

2.6.2. Preparation of Tablet Extracts and Assay Procedure. Fifty Oglo-15 tablets (each tablet contained $15.0 \mathrm{mg}$ PGZ) and twenty five Neoglit-30 (each tablet contained $30.0 \mathrm{mg}$ PGZ) were weighed and powdered. Tablet powder equivalent to $20 \mathrm{mg}$ of PGZ was transferred in to $100 \mathrm{~mL}$ volumetric flasks and $60 \mathrm{~mL}$ of the mobile phase were added. The solution sonicated for $20 \mathrm{~min}$ to achieve complete dissolution of PGZ, made up to the mark with mobile phase and then filtered through $0.22 \mu \mathrm{m}$ nylon membrane filter. The solution $\left(200 \mu \mathrm{g} \mathrm{mL}^{-1}\right)$ in PGZ) obtained was analysed.

2.6.3. Procedure for the Analysis of Placebo Blank and Synthetic Mixture. A placebo blank containing starch $(10 \mathrm{mg})$, acacia (15 mg), hydroxyl cellulose (10 mg), sodium citrate (10 mg), talc $(20 \mathrm{mg})$, magnesium stearate $(15 \mathrm{mg})$, and sodium alginate $(10 \mathrm{mg})$ was made and its solution was prepared as 
described under tablets and then subjected to analysis. A synthetic mixture was separately prepared by adding pure PGZ $(100 \mathrm{mg})$ to the above and the mixture was homogenized. Prepared a solution containing $200 \mu \mathrm{g} \mathrm{mL} \mathrm{L}^{-1}$ of PGZ was prepared from the above and extracted as described for tablets. The extracts containing three different concentrations of PGZ were subjected to assay by following the general procedures and the percentage recovery of PGZ was evaluated.

\subsubsection{Procedure for Method Validation}

Accuracy and Precision. To determine the accuracy and intra-day precision, pure PGZ solutions at three different concentrations were analyzed in seven replicates during the same day. The same procedure was followed in different days for the inter day precision. Mobile phase was injected as blank solution before sample injection and the RSD (\%) values of peak area and retention time were calculated.

Limits of Detection (LOD) and Quantification (LOQ). The LOD and LOQ were obtained by signal to noise $(S / N)$ ratio method [49]. LOQ and LOD were obtained by a series of dilutions of the PGZ stock solution. Precision study was performed at LOQ level also. LOQ solution was injected seven times $(n=7)$ and calculated the \% RSD values for the obtained peak area and retention time.

Linearity. Linearity solutions were prepared from LOQ level to $150 \%$ of the actual sample concentration $\left(200 \mu \mathrm{g} \mathrm{mL} \mathrm{L}^{-1}\right.$ PGZ). A total of six concentrations of the solutions were made separately and injected (LOQ, 50, 100, 150, 200, 250 and $300 \mu \mathrm{g} \mathrm{mL}^{-1}$ levels).

Robustness and Ruggedness. To determine the robustness of the method the experimental conditions were deliberately changed. The flow rate of the mobile phase $\left(0.2 \pm 0.02 \mathrm{~mL} \mathrm{~min}^{-1}\right)$, column oven temperature $(25 \pm$ $\left.1^{\circ} \mathrm{C}\right)$, mobile phase composition $(15: 85,25: 75$, acetonitrile: buffer, $\mathrm{v} / \mathrm{v})$, and detection wavelength $(220 \pm 1 \mathrm{~nm})$ were the varied parameters. In each case the $\%$ RSD values were calculated for the obtained peak area and retention time. The number of theoretical plates and tailing factors were compared with those obtained under the optimized conditions. Three different columns of same dimensions were used for the analyses. The studies were performed on the same day and on three different days by three different analysts for three different concentrations of PGZ (triplicate injections). The area obtained from each concentration was compared with that of the optimized one. The relative standard deviation values were evaluated for each concentration.

Solution Stability and Mobile Phase Stability. Stability of PGZ solution was investigated by injecting the sample into the chromatographic system at equal interval of time. The peak area was recorded in the time intervals of 0,12 and $24 \mathrm{hrs}$ and the RSD values were calculated. The mobile phase stability was studied by injecting a freshly prepared sample solution at the same time intervals $(0,12$, and 24 hours $)$ with the

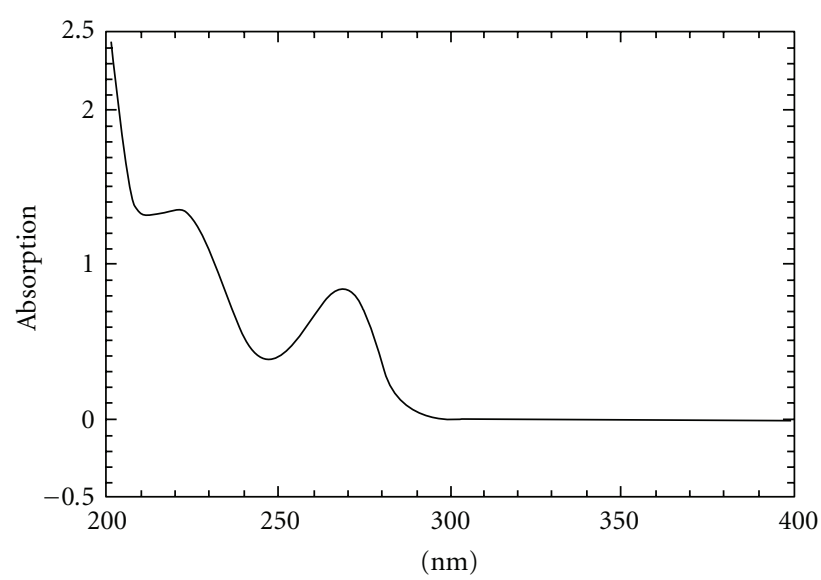

FIgURE 2: UV absorption spectra of pioglitazone $\mathrm{HCl}$.

same mobile phase and RSD values of the peak areas were calculated.

\section{Results}

The wavelength for detection was obtained from the UV absorption spectra of the sample solution (Figure 2).

Method Development for Acquity BEH C8 Column, $(100 \times$ 2.1) $\mathrm{mm}, 1.7 \mu \mathrm{m}$. All the trials are as shown in Table 1 and chromatograms are as shown in Figure 3.

Method Development for Acquity BEH C18, $(100 \times 2.1) \mathrm{mm}$, $1.7 \mu \mathrm{m}$ Column. All the trials are as shown in Table 2 and chromatograms are as shown in Figure 4.

Method Development for C18 Using Different pH Conditions. All the trials are as shown in Table 3 and chromatograms are as shown in Figure 5.

3.1. Final Method Conditions. Column: Acquity BEH C18, $(100 \times 2.1) \mathrm{mm}, 1.7 \mu \mathrm{m}$; oven temp.: $25^{\circ} \mathrm{C}$. Mobile phase: ACN : buffer (pH 3.2) $(20: 80 \% \mathrm{v} / \mathrm{v})$; run time: 5 min. Flow rate: $0.2 \mathrm{~mL} / \mathrm{min}$; diluent: mobile phase. Injection volume: $2 \mu \mathrm{L}$ blank: diluent. Wavelength: $220 \mathrm{~nm}$.

3.2. Validation of the Method. The described method for the assay of PGZ was validated as per the current ICH Q2 (R1) Guidelines.

3.2.1. Linearity and Sensibility. A calibration curve was obtained for PGZ from LOQ to $150 \%$ of its stock solution. A linear correlation was obtained between the mean peak area and the concentration in the range of $0.05-300 \mu \mathrm{g} \mathrm{mL}^{-1}$ PGZ. The LOD and LOQ values, slope $(m), y$-intercept $(a)$, and their standard deviations are evaluated and presented in Table 4 .

3.2.2. Accuracy and Precision. The results obtained for the evaluation of precision and accuracy of the method is compiled in Tables 5 and 6 . The percent relative error which 
TABLE 1: Observation and remarks of method development for Acquity BEH C8, $(100 \times 2.1) \mathrm{mm}, 1.7 \mu \mathrm{m}$ Column.

\begin{tabular}{llll}
\hline S. No. & Trails taken & Observations & Remarks \\
\hline 1 & ACN $:$ buffer $(\mathrm{pH} 3.2)(20: 80 \% \mathrm{v} / \mathrm{v})$ & Asymmetrical peak with fronting and tailing & Not Satisfactory \\
2 & ACN $:$ water $(20: 80 \% \mathrm{v} / \mathrm{v})$ & Asymmetrical peak with tailing & Not Satisfactory \\
3 & Methanol $:$ water $(20: 80 \% \mathrm{v} / \mathrm{v})$ & Split peak & Not Satisfactory \\
4 & Methanol $:$ buffer $(\mathrm{pH} 3.2)(20: 80 \% \mathrm{v} / \mathrm{v})$ & Asymmetrical peak & Not Satisfactory \\
\hline
\end{tabular}

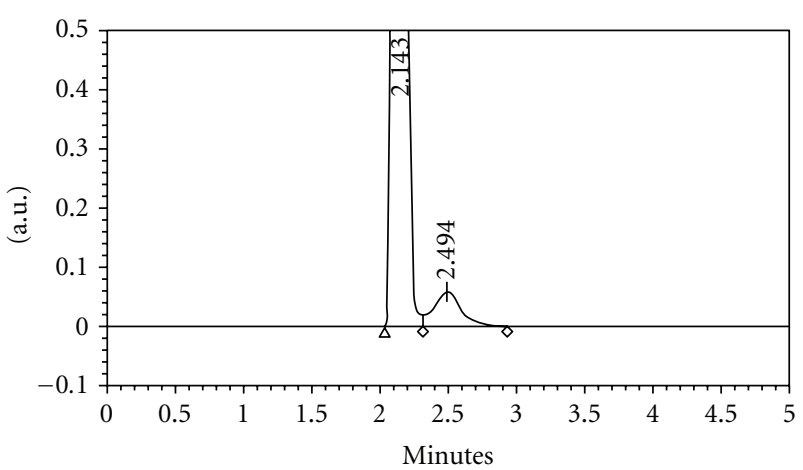

(a) ACN : Buffer (pH 3.2) $(20: 80 \% \mathrm{v} / \mathrm{v})$

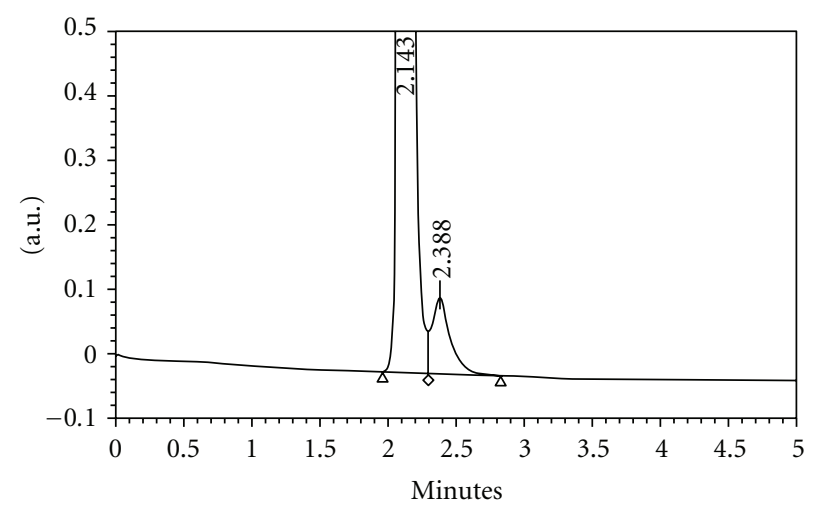

(c) Methanol: Water $(20: 80 \% \mathrm{v} / \mathrm{v})$

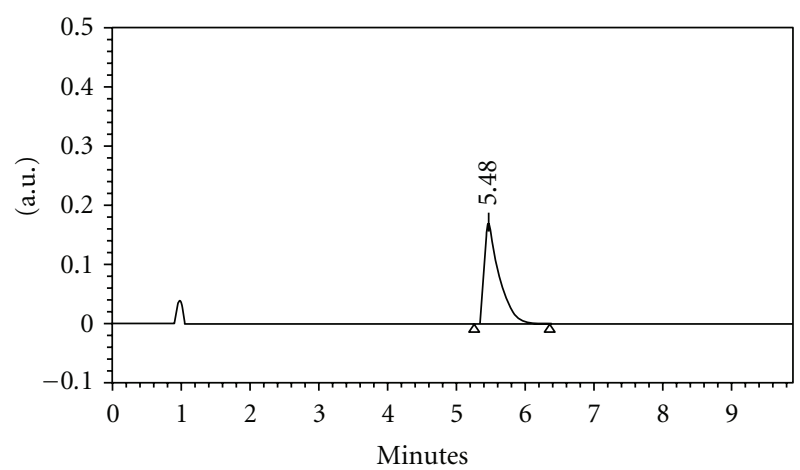

(b) ACN : Water $(20: 80 \% \mathrm{v} / \mathrm{v})$

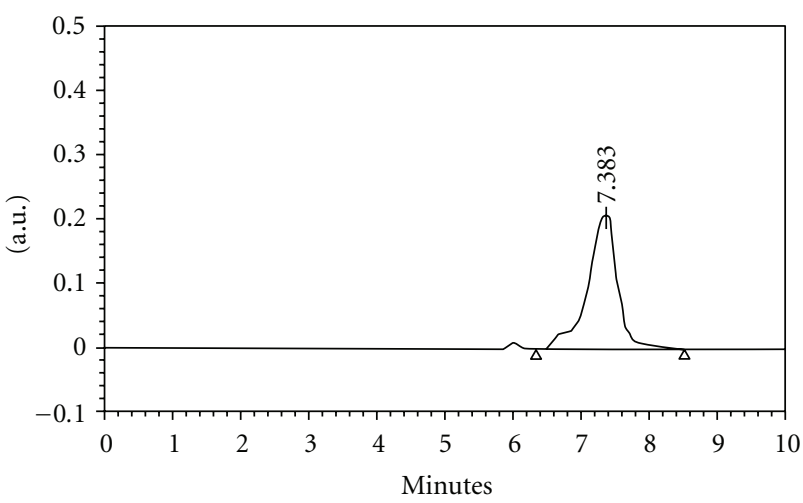

(d) Methanol: Buffer (pH 3.2) (20:80\% v/v)

FIGURE 3: Chromatograms obtained for method development using Acquity BEH C18, $(50 \times 2.1) \mathrm{mm}, 1.7 \mu \mathrm{m}$ column.

TABLE 2: Observation and remarks of method development for Acquity BEH C18, $(100 \times 2.1) \mathrm{mm}, 1.7 \mu \mathrm{m}$ column.

\begin{tabular}{llll}
\hline S. No. & Trails taken & Observations & Remarks \\
\hline 1 & ACN $:$ buffer $(\mathrm{pH} 3.2)(20: 80 \% \mathrm{v} / \mathrm{v})$ & Symmetrical peak & Satisfactory \\
2 & ACN $:$ water $(20: 80 \% \mathrm{v} / \mathrm{v})$ & Asymmetrical peak with tailing and early elution & Not Satisfactory \\
3 & Methanol $:$ water $(20: 80 \% \mathrm{v} / \mathrm{v})$ & Very broad peak & Not Satisfactory \\
4 & Methanol $:$ buffer $(\mathrm{pH} 3.2)(20: 80 \% \mathrm{v} / \mathrm{v})$ & Broad peak & Not Satisfactory \\
\hline
\end{tabular}

TABLE 3: Observation and remarks of method development for different $\mathrm{pH}$ conditions with Acquity BEH C18, $(100 \times 2.1) \mathrm{mm}, 1.7 \mu \mathrm{m}$ column.

\begin{tabular}{|c|c|c|c|c|c|}
\hline S. No. & Trails taken & Observations & Remarks & Theoretical plates & $\begin{array}{l}\text { Tailing } \\
\text { factor }\end{array}$ \\
\hline 1 & ACN : buffer (pH 3.2) $(20: 80 \% \mathrm{v} / \mathrm{v})$ & Peaks found symmetrical & Satisfactory & 3330 & 1.02 \\
\hline 2 & ACN : buffer (pH 4) $(20: 80 \% \mathrm{v} / \mathrm{v})$ & Peak eluted early with less theoretical plates & Not satisfactory & 1291 & 1.03 \\
\hline 3 & ACN : buffer (pH 5) $(20: 80 \% \mathrm{v} / \mathrm{v})$ & Completely split peak & Not satisfactory & 750 & 2.12 \\
\hline 4 & ACN : buffer (pH 6) $(20: 80 \%$ v/v) & Completely split peak & Not satisfactory & 800 & 3.89 \\
\hline
\end{tabular}




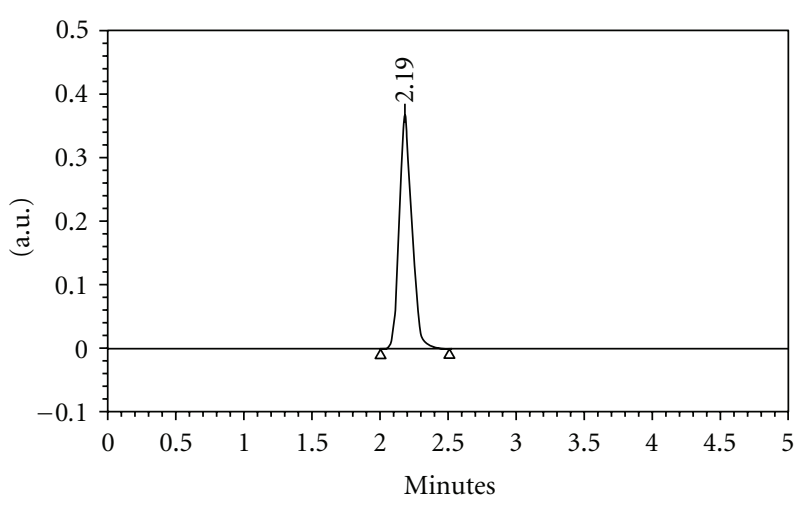

(a) ACN : Buffer (pH 3.2) (20:80\% v/v)

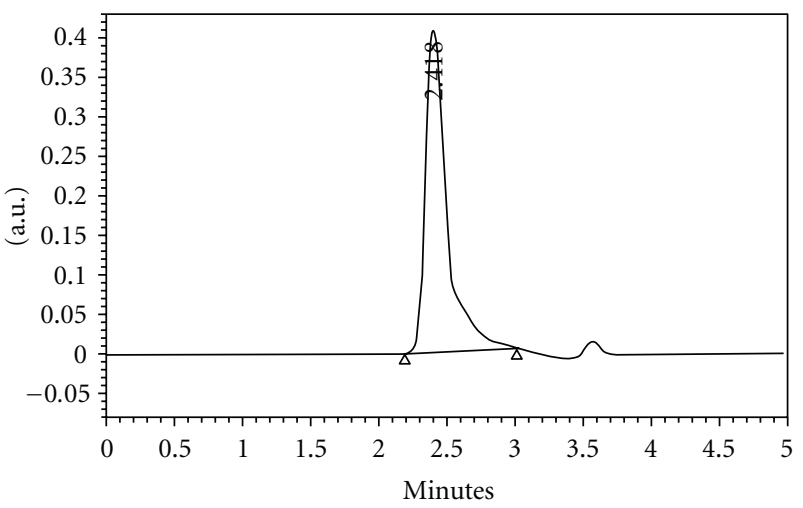

(c) Methanol: Water $(20: 80 \% \mathrm{v} / \mathrm{v})$

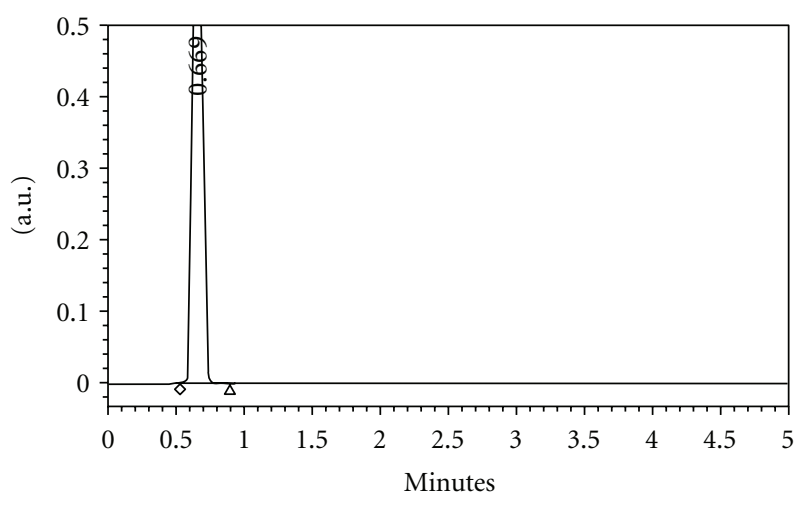

(b) ACN : Water $(20: 80 \% \mathrm{v} / \mathrm{v})$

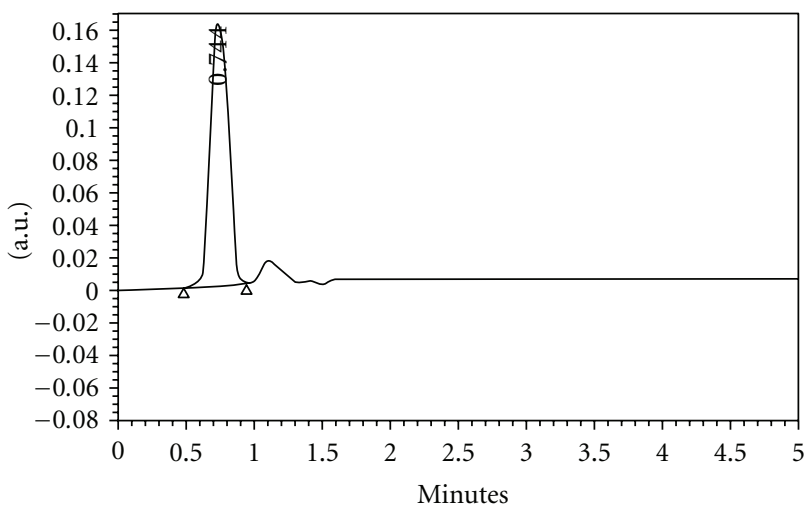

(d) Methanol: Buffer (pH3.2) (20:80\% v/v)

FIgURE 4: Chromatograms obtained for method development using Acquity BEH C18, $(100 \times 2.1) \mathrm{mm}, 1.7 \mu \mathrm{m}$ column.

TABLE 4: Linearity and regression parameters with precision data.

\begin{tabular}{lc}
\hline Parameter & Value \\
\hline Linear range, $\mu \mathrm{g} \mathrm{mL}^{-1}$ & $0.05-300$ \\
Limits of quantification, (LOQ), $\mu \mathrm{g} \mathrm{mL}^{-1}$ & 0.05 \\
Limits of detection, (LOD), $\mu \mathrm{g} \mathrm{mL}^{-1}$ & 0.01 \\
Regression equation & \\
$\quad$ Slope $(b)$ & 1989.854 \\
Intercept $(a)$ & 1017778.100 \\
Correlation coefficient $(r)$ & 0.9999 \\
Standard deviation of $b,\left(S_{b}\right)$ & 101.547 \\
Standard deviation of $a,\left(S_{a}\right)$ & 16839.785 \\
\hline
\end{tabular}

is an index of accuracy is $\leq 1.5$ and is indicative of high accuracy. The calculated percent relative standard deviation (\%RSD) can be considered to be satisfactory. The peak area based and retention time based RSD values were $<1$.

3.2.3. Robustness and Ruggedness. The robustness of an analytical procedure is a measure of its capacity to remain unaffected by small, but deliberate variations in method parameters and provides an indication of its reliability during normal usage. At the deliberate varied chromatographic conditions (flow rate, temperature, and mobile phase composition), the analyte peak \% RSD, tailing factor and theoretical plates remained near to the values obtained under optimum conditions. The RSD values ranged from 0.1 to $1.0 \%$ resumes the robustness of the proposed method. In method ruggedness, different columns (same lot) days and analysts $(n=3)$ were performed. The results were summarized in Table 7.

3.2.4. Stability of the Solution. At the specified time interval, $\%$ RSD for the peak area obtained from drug solution stability and mobile phase stability were within $1 \%$. This shows no significant change in the elution of the peak and its system suitability criteria (\%RSD, tailing factor, theoretical plates). The results also confirmed that the standard solution of drug and mobile phase were stable at least for 24 hours during the assay performance.

3.2.5. Selectivity. Selectivity of the method was evaluated by injecting the mobile phase, placebo blank, pure drug solution, and tablet extract. No peaks were observed for mobile phase and placebo blank and no extra peaks were observed for tablet extracts (Figures 6(a) and 6(b)).

\section{Application to Tablet Analysis}

A $200 \mu \mathrm{g} \mathrm{mL}^{-1}$ solution of tablets was prepared as per "preparation of tablet extracts and assay procedure" and injected in triplicate to the UPLC system. From the mean peak area, 


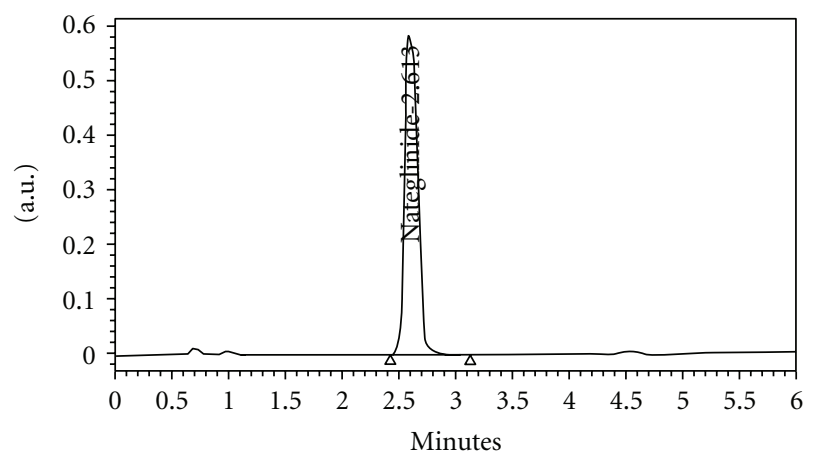

(a) ACN : Buffer (pH 3.2) (20:80\% v/v)

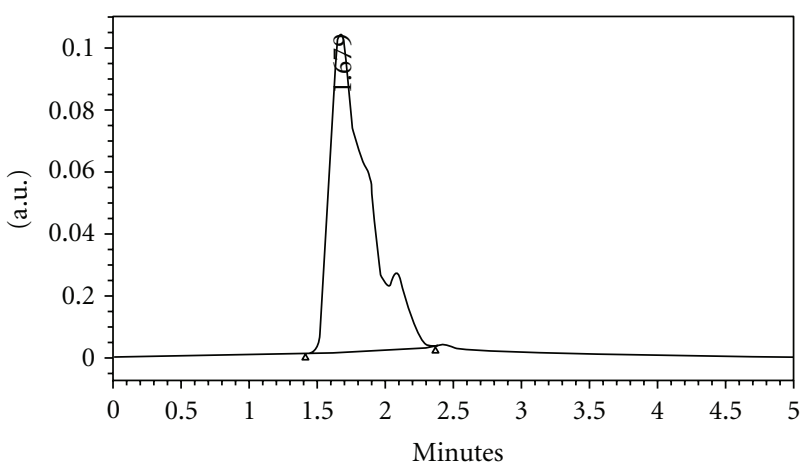

(c) ACN : Buffer (pH 2.2) $(20: 80 \% \mathrm{v} / \mathrm{v})$

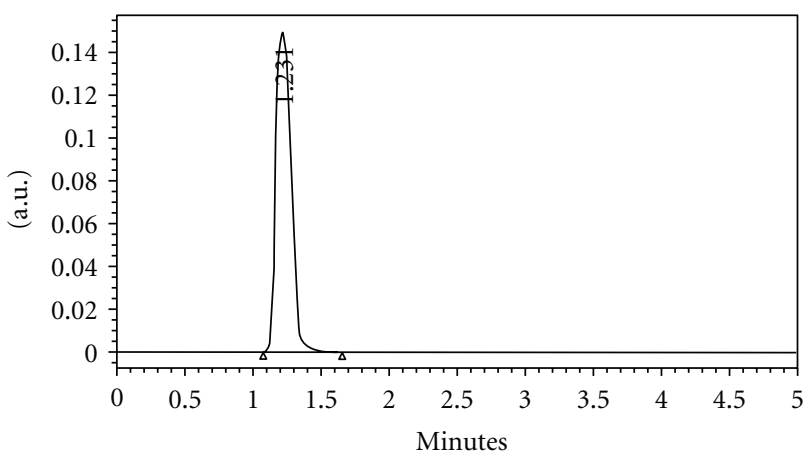

(b) ACN : Buffer (pH 4.2) $(20: 80 \% \mathrm{v} / \mathrm{v})$

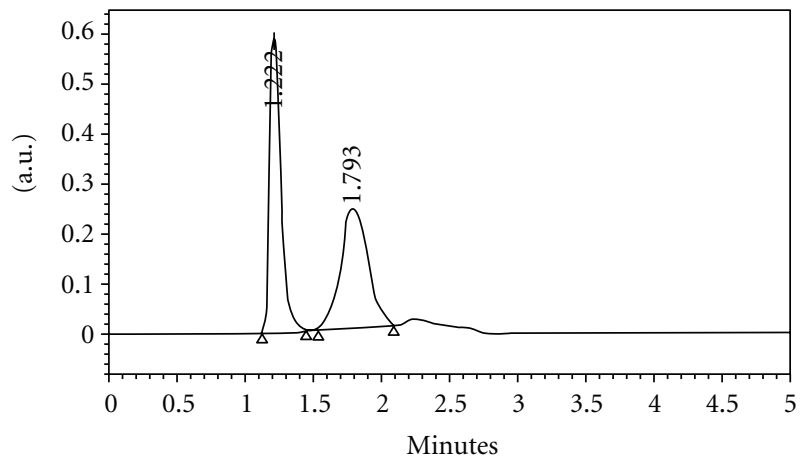

(d) ACN : Buffer (pH 5.5) $(20: 80 \% \mathrm{v} / \mathrm{v})$

Figure 5: Chromatograms obtained for method development using Acquity BEH C18, $(100 \times 2.1) \mathrm{mm}, 1.7 \mu \mathrm{m}$ column at different pH conditions.

TABLE 5: Results of accuracy study $(n=5)$.

\begin{tabular}{|c|c|c|c|c|}
\hline \multirow{2}{*}{ Concentration of PGZ injected, $\mu \mathrm{g} \mathrm{mL}^{-1}$} & \multicolumn{2}{|l|}{ Intra-day } & \multicolumn{2}{|l|}{ Inter-day } \\
\hline & Concentration of PGZ found, $\mu \mathrm{g} \mathrm{mL}-1$ & $\mathrm{RE}^{\mathrm{a}}, \%$ & Concentration of PGZ found, $\mu \mathrm{g} \mathrm{mL}^{-1}$ & $\mathrm{RE}, \%$ \\
\hline 100 & 102.34 & 2.34 & 98.47 & 1.53 \\
\hline 200 & 202.12 & 1.06 & 203.21 & 1.61 \\
\hline 300 & 304.12 & 1.37 & 302.45 & 0.82 \\
\hline
\end{tabular}

a Relative error.

TABLE 6: Results of precision study.

\begin{tabular}{|c|c|c|c|c|}
\hline \multicolumn{5}{|c|}{ Intra-day precision $(n=7)$} \\
\hline Concentration injected $\left(\mu \mathrm{g} \mathrm{mL}^{-1}\right)$ & Mean area \pm SD & $\mathrm{RSD}^{\mathrm{a}}$ & Mean $\mathrm{RT} \pm \mathrm{SD}$ & $\mathrm{RSD}^{\mathrm{b}}$ \\
\hline 100 & $222879 \pm 1648$ & 0.74 & $2.19 \pm 0.004$ & 0.16 \\
\hline 200 & $502609 \pm 590$ & 0.12 & $2.19 \pm 0.007$ & 0.32 \\
\hline 300 & $755267 \pm 2276$ & 0.30 & $2.20 \pm 0.002$ & 0.09 \\
\hline \multicolumn{5}{|c|}{ Inter-day precision $(n=5)$} \\
\hline Concentration injected $\left(\mu \mathrm{g} \mathrm{mL}^{-1}\right)$ & Mean area \pm SD & $\mathrm{RSD}^{\mathrm{a}}$ & Mean $\mathrm{RT} \pm \mathrm{SD}$ & $\mathrm{RSD}^{\mathrm{b}}$ \\
\hline 100 & $223992 \pm 1130$ & 0.50 & $2.19 \pm 0.024$ & 1.08 \\
\hline 200 & $501345 \pm 3070$ & 0.61 & $2.19 \pm 0.015$ & 0.67 \\
\hline 300 & $754190 \pm 1555$ & 0.21 & $2.18 \pm 0.011$ & 0.52 \\
\hline
\end{tabular}

${ }^{a}$ Relative standard deviation based on peak area.

${ }^{\mathrm{b}}$ Relative standard deviation based on retention time. 


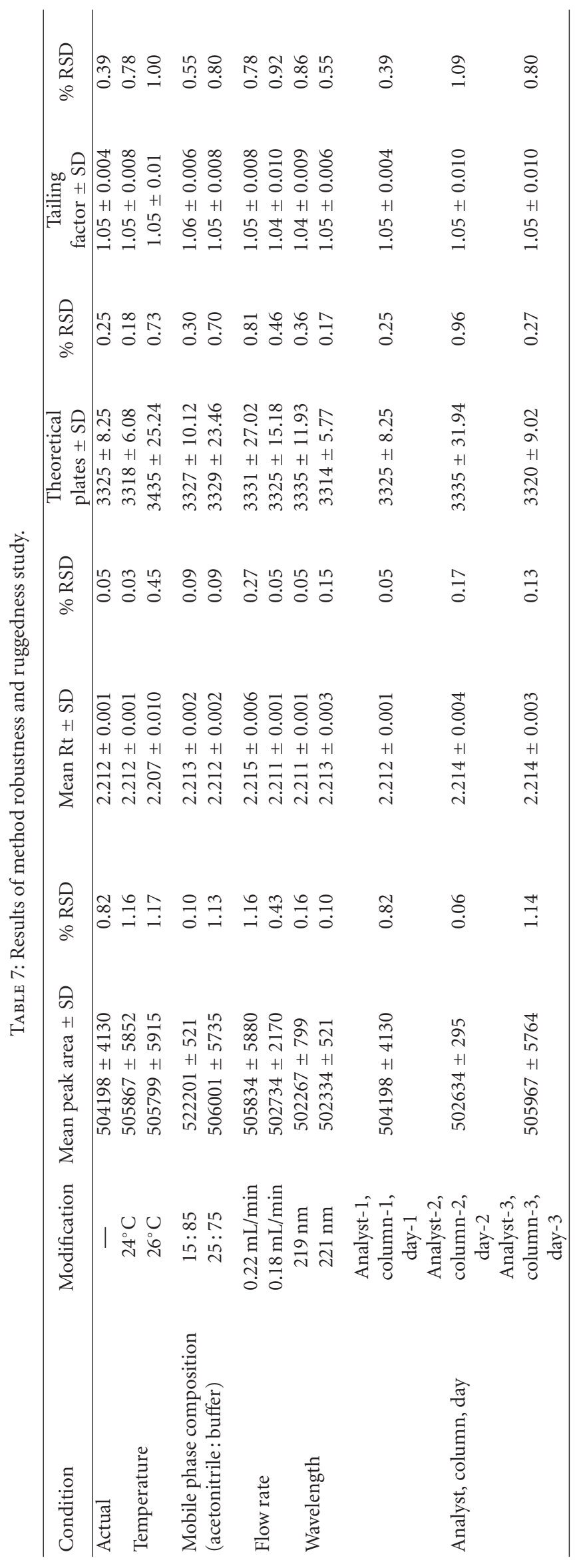




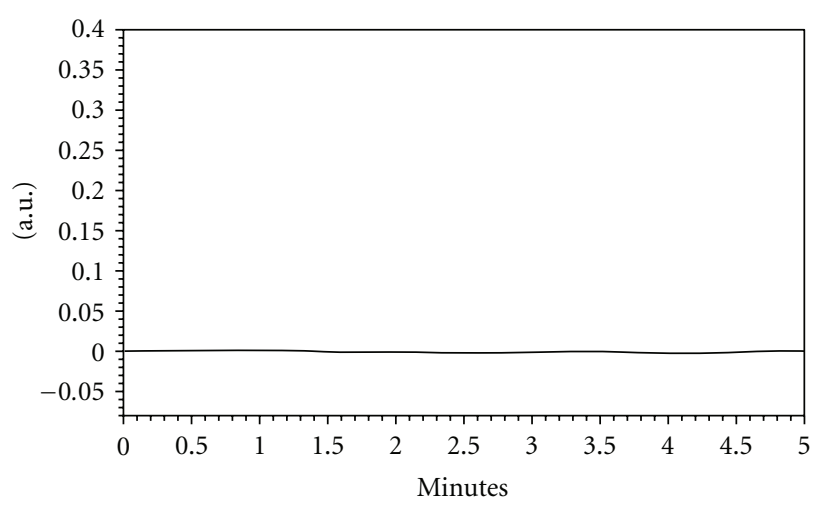

(a) Placebo blank

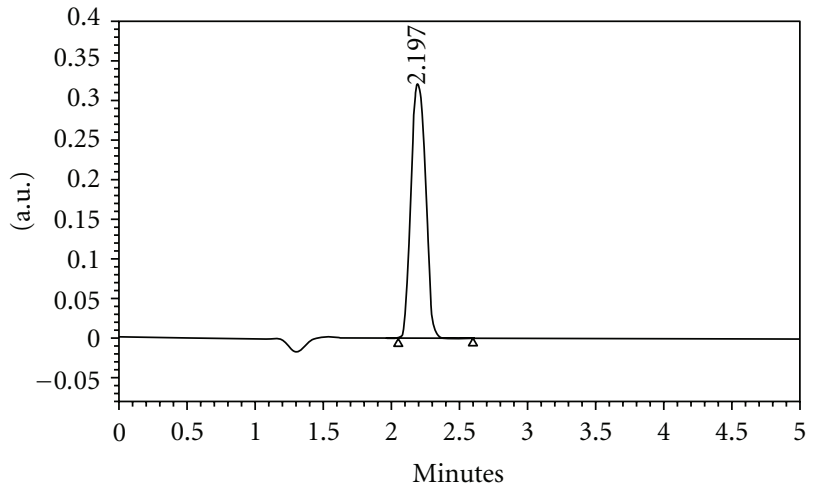

(b) Tablet extract

FIGURE 6: Chromatograms obtained for placebo blank and tablet extract.

TABLE 8: Results of determination of PGZ in formulations and statistical comparison with the reference method.

\begin{tabular}{|c|c|c|c|c|c|}
\hline \multirow{2}{*}{ Formulation brand name $\mathrm{a}^{\mathrm{a}}$} & \multirow{2}{*}{ Nominal amount, mg } & \multicolumn{2}{|c|}{$\%$ PGZ found ${ }^{\mathrm{c}} \pm \mathrm{SD}$} & \multirow{2}{*}{$t$-value } & \multirow{2}{*}{$F$-value } \\
\hline & & Reference method & Proposed method & & \\
\hline Oglo- $15^{a}$ & 30.0 & $99.01 \pm 0.82$ & $98.88 \pm 0.68$ & 0.33 & 1.73 \\
\hline Neoglit- $30^{\mathrm{b}}$ & 15.0 & $101.2 \pm 0.75$ & $99.94 \pm 0.97$ & 1.63 & 1.40 \\
\hline
\end{tabular}

${ }^{a}$ Marketed by Panacea biotec, Mumbai, India.

${ }^{\mathrm{b}}$ Marketed by Novus Life Sciences Private Limited, Mumbai, India.

${ }^{\mathrm{c}}$ Mean value of five determinations. Tabulated $t$-value at $95 \%$ confidence level is 2.78 ; tabulated $F$-value at $95 \%$ confidence level is 6.39 .

the concentration and hence $\mathrm{mg} /$ tablet were computed; and the results were compared with those of a reference method [19]. The reference method involved the HPLC analysis with ammonium acetate buffer in acetonitrile and glacial acetic acid $(25: 25: 1)$, wavelength was set at $269 \mathrm{~nm}$ and $4.6-\mathrm{mm}$, $15-\mathrm{cm} ; 5-\mu \mathrm{m}$ packing L1 column was used. The accuracy and precision of the proposed method were further evaluated by applying Student's $t$-test $(<2.7)$ and variance ratio $F$-test $(<6.4)$, respectively. The $t$ - and $F$-values at $95 \%$ confidence level did not exceed the tabulated values and this further confirms that there is no significant difference between the reference and proposed methods with respect to accuracy and precision. Table 8 illustrates the results obtained from this study.

\section{Recovery Study}

A standard addition procedure was followed to evaluate the accuracy of the method. The sample is analysed for the analyte of interest by adding a specified amount of this analyte to the sample, thus increasing its concentration. The percentage recovery of PGZ from pharmaceutical dosage forms ranged from $97.4 \%$ to $101.4 \%$. Detailed results presented in Table 9 reveal good accuracy of the proposed method.

\section{Stress Study}

No degradation products were observed during the stress studies with $1 \mathrm{M} \mathrm{HCl}$, neutral, thermal, and photolytic conditions. Significant degradation was observed with $1 \mathrm{M}$ $\mathrm{NaOH}$ and $5 \% \mathrm{H}_{2} \mathrm{O}_{2}$. Figure 7 shows the degradation chromatograms of PGZ with the corresponding solvent as blank.

\section{Conclusion}

A reversed phase UPLC method development approach using QbD principles has been described. The Quality by Design project aims to encourage debate about quality in the complete development of the drug in a systematic manner. This paper has reviewed literature on ideas, research, policy, and practice about quality in determination of PGZ as much about what we think as what we know. First, the method goals are clarified based on the process understanding. The experimental design describes the scouting of the key UPLC method components including column, $\mathrm{pH}$, and mobile phase. The interrelationships are studied and the preliminary optimized conditions are obtained for each combination. Here a better understanding of the factors influencing chromatographic separation and greater confidence in the ability of the methods to meet their intended purposes is done. Moreover, this approach ensures better design of products with fewer problems in development, reduces the number of trials required for post-market changes, relies more on process, and understanding and mitigation of risk, allows implementation of new technology to improve manufacturing without regulatory scrutiny, enables possible reduction in overall costs of manufacturing resulting in less waste. The validated method is specific, linear, precise, accurate, robust, rugged, and stable for 24 hours and can be applied for the determination in formulated form. The drug is stable in acidic, thermal, photolytic, and hydrolytic conditions and degrades in basic, oxidative conditions. The 
TABLE 9: Results of recovery study by standard addition method.

\begin{tabular}{lcccc}
\hline Tablet studied & $\begin{array}{c}\text { PGZ } \mu \mathrm{g} \mathrm{mL} \mathrm{m}^{-1}, \\
\text { tablet }\end{array}$ & PGZ $\mu \mathrm{g} \mathrm{mL}^{-1}$, pure & $\begin{array}{c}\text { Total PGZ found, } \\
\mu \mathrm{g} \mathrm{mL} \mathrm{m}^{-1}\end{array}$ & $\begin{array}{c}\text { Percent recovery of } \\
\text { pure PGZ } \\
(\% \mathrm{PGZ} \pm \mathrm{SD})\end{array}$ \\
\hline \multirow{3}{*}{ Oglo-15 } & 48.58 & 50 & 99.56 & $100.99 \pm 0.81$ \\
& 48.58 & 150 & 196.53 & $98.97 \pm 0.48$ \\
\hline \multirow{3}{*}{ Neoglit-30 } & 48.58 & 250 & 299.13 & $100.18 \pm 0.68$ \\
& 48.52 & 50 & 100.12 & $101.62 \pm 0.85$ \\
& 48.52 & 150 & 195.16 & $98.31 \pm 0.59$ \\
\hline
\end{tabular}

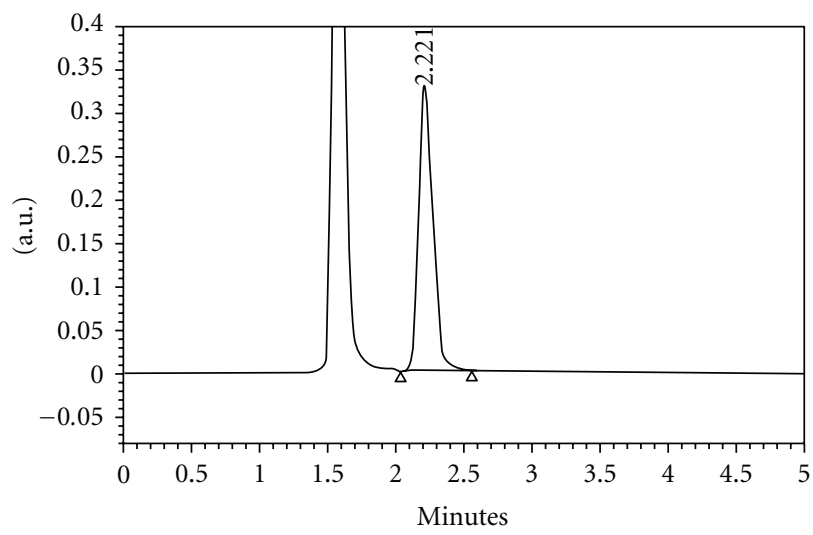

(a) $5 \% \mathrm{H}_{2} \mathrm{O}_{2}$ degradation

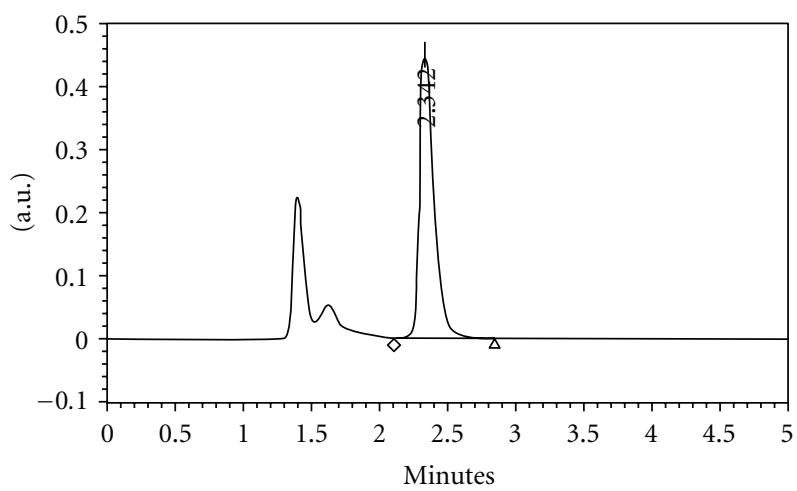

(c) $5 \mathrm{~N} \mathrm{NaOH}$ degradation

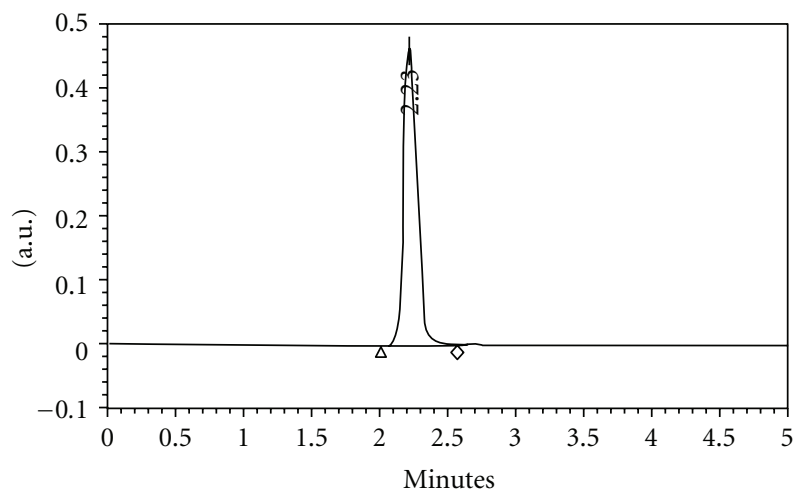

(e) Thermal degradation

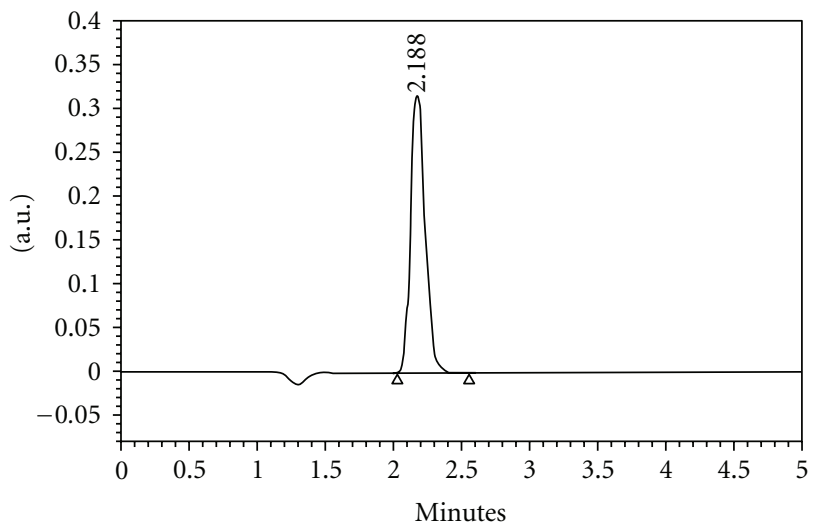

(b) $5 \mathrm{~N} \mathrm{HCl}$ degradation

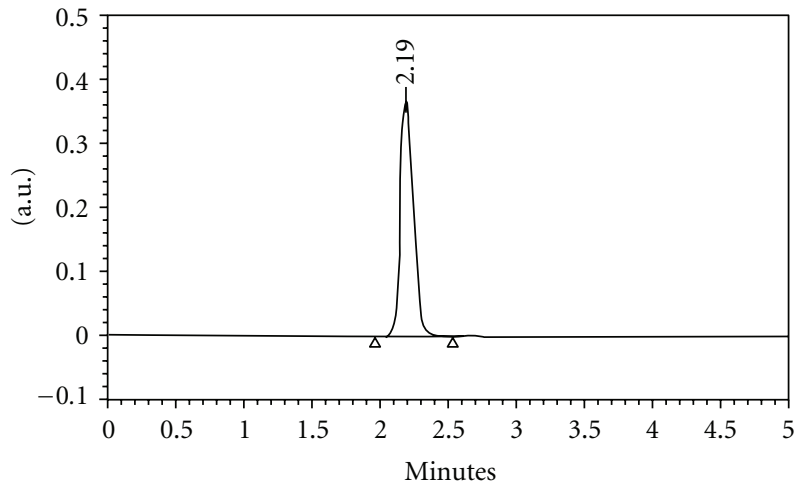

(d) $\mathrm{H}_{2} \mathrm{O}$ degradation

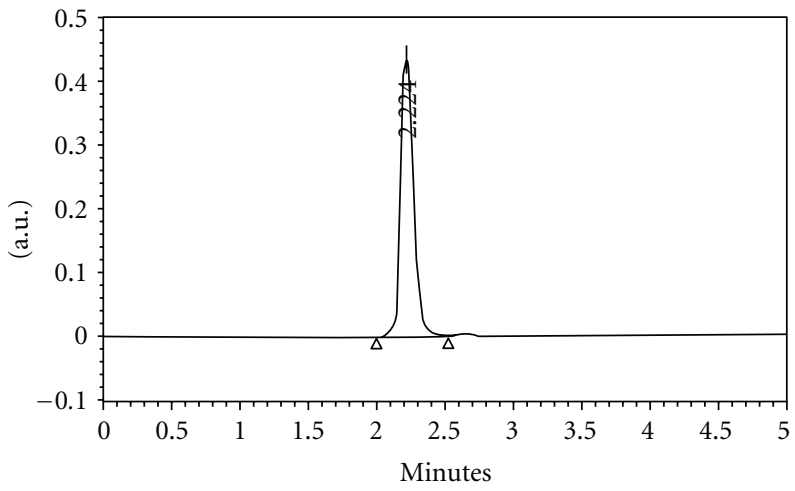

(f) Photolytic degradation

FIGURE 7: Chromatograms obtained for forced degradation. 
potential of $\mathrm{QbD}$ approach for simultaneous development of multiple methods including impurity methods, assay method, dissolution method, cleaning validation method, and so forth should be implemented.

\section{Acknowledgments}

The authors thank Glenmark Pharmaceuticals, Mumbai, India, for gifting pure pioglitazone hydrochloride. They are also thankful to the University of Mysore for providing the permission and facilities to do research work. C. M. Xavier is grateful to Jubilant Life Sciences, Nanjangud, Mysore, for permission to pursue Ph.D. degree programme.

\section{References}

[1] "International conference on harmonisation of technical requirements for registration of pharmaceuticals for human use," Step 4ICH Q8 (R) step-2, 2009.

[2] Y. Tang, "Quality by design approaches to analytical methodsFDA perspective," http://www.fda.gov/downloads/AboutFDA/ CentersOffices/OfficeofMedicalProductsandTobacco/CDER/ UCM301056.pdf.

[3] "International Conference on Harmonization of technical requirements for registration of pharmaceuticals for human use, ICH harmonized tripartite guideline," Pharmaceutical Development Q8(R1), Draft Step 4. 2008.

[4] L. X. Yu, "Pharmaceutical quality by design: product and process development, understanding, and control," Pharmaceutical Research, vol. 25, no. 4, pp. 781-791, 2008.

[5] S. L. Lee, A. S. Raw, and L. Yu, "Preformulation in solid dosage form development," in Significance of Drug Substance Physiochemical Properties in Regulatory Quality By Design. Drugs and the Pharmaceutical Sciences, pp. 571-583, Informa Healthcare, London, UK, 2008.

[6] R. Mhatre and A. S. Rathore, Quality by Design: An Overview of the Basic Concepts. Quality By Design For Biopharmaceuticals, John Wiley \& Sons, New York, NY, USA, 2009.

[7] F. G. Vogt and A. S. Kord, "Development of quality-by-design analytical methods," Journal of Pharmaceutical Sciences, vol. 100, no. 3, pp. 797-812, 2011.

[8] Y. Li, G. J. Terfloth, and A. S. Kord, "A systematic approach to RP-HPLC method development in a pharmaceutical QbD environment," American Pharmaceutical Review, vol. 12, no. 4, pp. 571-583, 2009.

[9] L. Zhou, J. M. Socha, F. G. Vogt, S. Chen, and A. S. Kord, "A systematic method development strategy for water determinations in drug substance using Karl Fischer titrations," American Pharmaceutical Review, vol. 13, no. 1, pp. 74-84, 2010.

[10] M. Sun, D. Q. Liu, and A. S. Kord, "A systematic method development strategy for determination of pharmaceutical genotoxic impurities," Organic Process Research and Development, vol. 14, no. 4, pp. 977-985, 2010.

[11] P. F. Gavin and B. A. Olsen, "A quality by design approach to impurity method development for atomoxetine hydrochloride (LY139603)," Journal of Pharmaceutical and Biomedical Analysis, vol. 46, no. 3, pp. 431-441, 2008.

[12] M. Schweitzer, M. Pohl, M. Hanna-Brown et al., "Implications and opportunities of applying QbD principles to analytical measurements," Pharmaceutical Technology, vol. 34, no. 2, pp. 52-59, 2010.

[13] P. Borman, P. Nethercote, M. Chatfield, D. Thompson, and K. Truman, "The application of quality by design to analytical methods," Pharmaceutical Technology, vol. 31, no. 10, pp. 142152, 2007.

[14] I. Krull, M. Swartz, J. Turpin, P. H. Lukulay, and R. Verseput, "A quality-by-design methodology for rapid LC method development, part I," LC-GC North America, vol. 26, no. 12, pp. 1190-1197, 2008.

[15] I. Krull, M. Swartz, J. Turpin, P. H. Lukulay, and R. Verseput, "A quality-by-design methodology for rapid LC method development, part II," LC-GC North America, vol. 27, no. 1, pp. 4861, 2009.

[16] M. J. O’Neil, The Merck Index, Merck Research Laboratories, 13th edition, 2001.

[17] M. M. Masadeh, N. M. Mhaidat, S. I. A. Azzam, and K. H. Alzoubi, "Investigation of the antibacterial activity of pioglitazone," Drug Design, Development and Therapy, vol. 5, pp. 421425, 2011.

[18] A. K. Saha, P. R. Avilucea, J. M. Ye, M. M. Assifi, E. W. Kraegen, and N. B. Ruderman, "Pioglitazone treatment activates AMPactivated protein kinase in rat liver and adipose tissue in vivo," Biochemical and Biophysical Research Communications, vol. 314, no. 2, pp. 580-585, 2004.

[19] The United States Pharmacopoeia XXXV Revision, The National Formulary Rockville, USP Convention, 2012.

[20] European Pharmacopoeia, “EDQM, version 7.7," pp. 50315032, 2012.

[21] Ismail, R. Rajavel, M. Ganesh et al., "RP-HPLC method for the simultaneous determination of aspirin, atorvastatin and pioglitazone in capsule dosage form," Asian Journal of Research in Chemistry, vol. 1, p. 40, 2008.

[22] K. Karthrik, G. Subramanian, C. M. Rao et al., "Simultaneous determination of pioglitazone and glimepiride in bulk drug and pharmaceutical dosage form by RP-HPLC method," Pakistan Journal of Pharmaceutical Sciences, vol. 21, no. 4, pp. 421425, 2008.

[23] K. S. Lakshmi, T. Rajesh, and S. Sharma, "Simultaneous determination of metformin and pioglitazone by reversed phase HPLC in pharmaceutical dosage forms," International Journal of Pharmacy and Pharmaceutical Sciences, vol. 1, no. 2, pp. 162-166, 2009.

[24] A. M. R. L. Saber, "Determination of pioglitazone hydrochloride in tabletsby high-performance liquid chromatography," Pakistan Journal of Analitical and Environmental Chemistry, vol. 9, no. 2, pp. 118-121, 2008.

[25] D. Srinivasulu, B. S. Sastry, and G. Omprakash, "Development and validation of new RPHPLC method for determination of pioglitazone hcl in pharmaceutical dosage forms," International Journal of Chemistry Research, vol. 1, no. 1, pp. 18-20, 2010.

[26] S. Sharma, M. C. Sharma, and S. C. Chaturvedi, "Study of stressed degradation behavior of pioglitazone hydrochloride in bulk and pharmaceutical formulation by HPLC assay method," Journal of Optoelectronics and Biomedical Materials, vol. 1, no. 1, pp. 17-24, 2010.

[27] S. Alexandar, R. Diwedi, and M. J. N. Chandrasekar, "A RPHPLC method for simultaneous estimation of metformin and pioglitazone in pharmaceutical formulation," Research Journal of Pharmaceutical, Biological and Chemical Sciences, vol. 1, no. 4, pp. 858-866, 2010.

[28] M. A. Jiladia, S. S. Pandya, and A. G. Jiladia, "Estimation of pioglitazone in bulk and tablet dosage forms by HPLC method," International Journal of Pharmaceutical Sciences, vol. 2, no. 1, pp. 386-389, 2010.

[29] F. H. Havaldar and D. L. Vairal, "Simultaneous estimation of metformin hydrochloride, rosiglitazone and pioglitazone 
hydrochloride in the tablets dosage form," International Journal of Applied Biology and Pharmaceutical Technology, vol. 1, no. 3, pp. 1000-1005, 2010.

[30] S. Havele and S. Dhaneshwar, "Development and validation of a HPLC method for the determination of metformin hydrochloride, gliclazide and piogliglitazone hydrochloride in multicomponent formulation," Webmed central.com, pp. 116, 2010.

[31] P. K. Chaturvedi and R. Sharma, "Development and validation of an RP-HPLC method for simultaneous analysis of a three-component tablet formulation containing metformin hydrochloride, pioglitazone hydrochloride, and glibenclamide," Acta Chromatographica, vol. 20, no. 3, pp. 451-461, 2008.

[32] K. Abro, N. Memon, M. I. Bhanger, S. A. Mahesar, and S. Perveen, "Liquid chromatographic determination of pioglitazone in pharmaceuticals, serum and urine samples," vol. 12, no. 1, pp. 49-54, 2011.

[33] Z. J. Lin, W. Ji, L. Shum, and D. D. Krieger, "Simultaneous determination of pioglitazone and its two active metabolites in human plasma by LC-MS/MS," Journal of Pharmaceutical and Biomedical Analysis, vol. 33, no. 1, pp. 101-108, 2003.

[34] K. S. Lakshmi, T. Rajesh, and S. Sharma, "Determination of pioglitazone and glimepiride in pharmaceutical formulations and rat plasma by RP-LC," International Journal of PharmTech Research, vol. 1, no. 3, pp. 496-499, 2009.

[35] P. Sripalakit, P. Neamhom, and A. Saraphanchotiwitthaya, "High-performance liquid chromatographic method for the determination of pioglitazone in human plasma using ultraviolet detection and its application to a pharmacokinetic study," Journal of Chromatography B, vol. 843, no. 2, pp. 164-169, 2006.

[36] N. Rashmithaa, S. G. Hiriyanna, C. H. S. Rao et al., "A validated stability indicating HPLC method for the determination of impurities in pioglitazone hydrochloride," Der Pharma Chemica, vol. 2, no. 5, pp. 426-433, 2010.

[37] M. A. Jiladia, S. S. Pandya, and G. Viidyasagar, "A simple and sensitive HPTLC method for estimation of pioglitazone inbulk and tablet dosage forms," Asian Journal of Research in Chemistry, vol. 2, no. 2, pp. 207-209, 2009.

[38] M. Amanlou, M. Zarei-Ghobadi, M. K. Rofouei, S. Saremi, and A. Kebriaeezadeh, "Extractive spectrophotometric method for determination of pioglitazone hydrochloride in raw material and tablets using ion-pair formation," E-Journal of Chemistry, vol. 7, no. 3, pp. 915-921, 2010.

[39] P. G. Sunithaa, N. Deattu, and N. Umaranib, "Spectrophotometric method for the determination of pioglitazone in pharmaceutical dosage forms," Der Pharma Chemica, vol. 2, no. 2, pp. 202-204, 2010.

[40] J. D. Bodar, S. Kumar, Y. C. Yadav et al., "Development of the spectrophotometric method for the simultaneous estimation of piogliazoneand metformin," Pharma Science Monitor. In press.

[41] P. Shakya and K. Singh, "Determination of pioglitazone hydrochloride in bulk and pharmaceutical formulations by UV spectrophotometric method," International Journal of Pharmaceutical Sciences and Research, vol. 1, no. 11, pp. 153157, 2010.

[42] F. Faridbod, M. R. Ganjali, E. Nasli-Esfahani, B. Larijani, S. Riahi, and P. Norouzi, "Potentiometric sensor for quantitative analysis of pioglitazone hydrochloride in tablets based on theoretical studies," International Journal of Electrochemical Science, vol. 5, no. 6, pp. 880-894, 2010.

[43] P. Sengupta, A. K. Sarkar, U. Bhaumik et al., "Development and validation of an LC-ESI-MS/MS method for simultaneous quantitation of olmesartan and pioglitazone in rat plasma and its pharmacokinetic application," Biomedical Chromatography, vol. 24, no. 12, pp. 1342-1349, 2010.

[44] M. Summers K. J. Fountain, "A Quality by Design (QbD) based methoddevelopment for the determination of impurities in a peroxide degraded sample of ziprasidone," LCGC Asia Pacific. In press.

[45] http://files.instrument.com.cn/bbs/upfile/images/20110707/ 201107071723125302.swf.

[46] L. Y. S. Narasimham and V. D. Barhate, "Development and validation of stability indicating UPLC method for the simultaneous determination of anti-diabetic drugs in pharmaceutical dosage forms," Journal of Pharmacy Research, vol. 3, no. 12, pp. 3081-3087, 2010.

[47] J. Simeone and P. D. Rainville, "A reproducible method for the quantification of pioglitazone and two active metabolitesketo pioglitazone and hydroxy pioglitazone-in human plasma using Xevo TQD MS and the ACQUITY UPLC H-class system," Waters corporation, 2012.

[48] Photostability Testing of New Active Substances and Medicinal Products, ICH Q1 (B), 1998.

[49] "International conference on harmonisation of technical requirements for registration of pharmaceuticals for human use, validation of analytical procedures: Steps and methodology," Step 5 ICH Q2 (R1), 1995. 


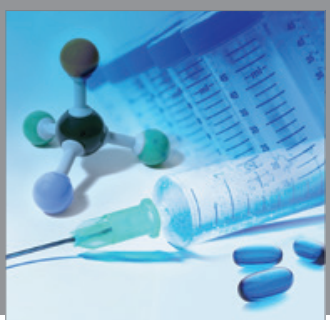

International Journal of

Medicinal Chemistry

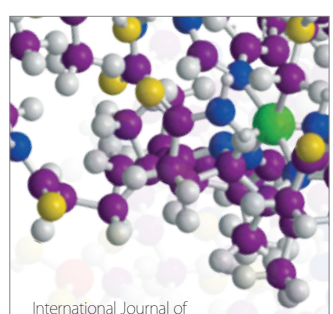

Carbohydrate Chemistry

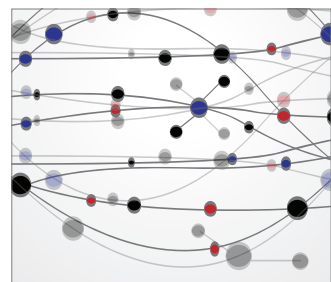

The Scientific World Journal
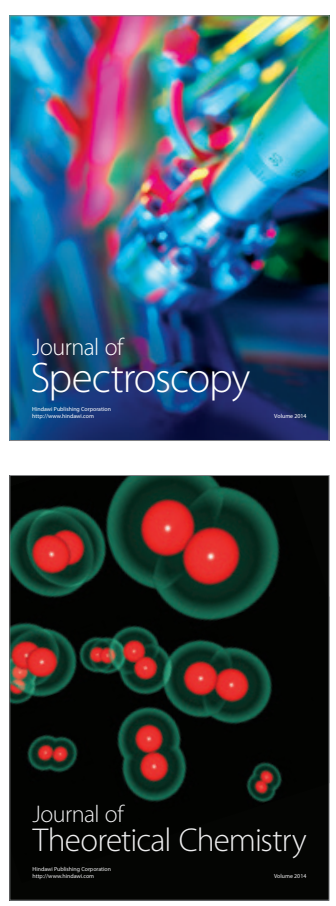
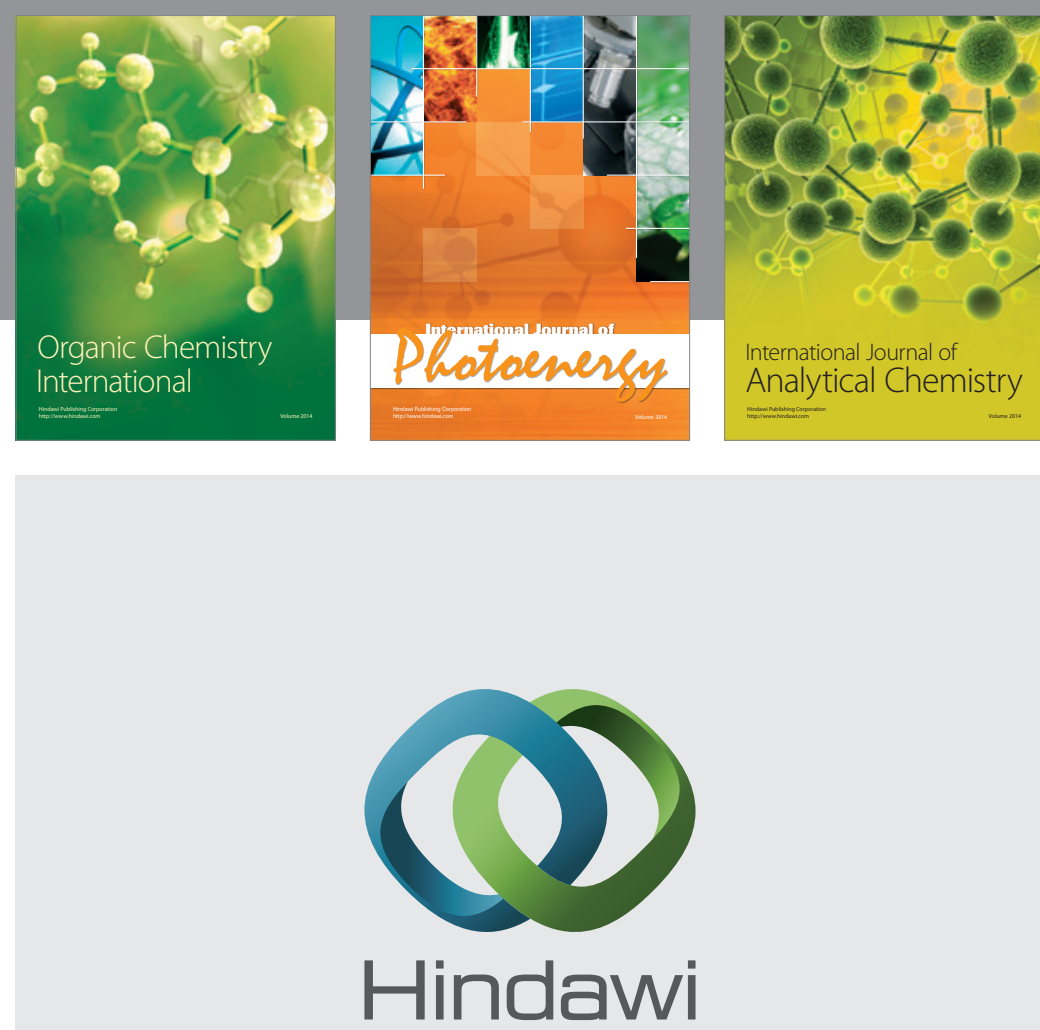

Submit your manuscripts at

http://www.hindawi.com
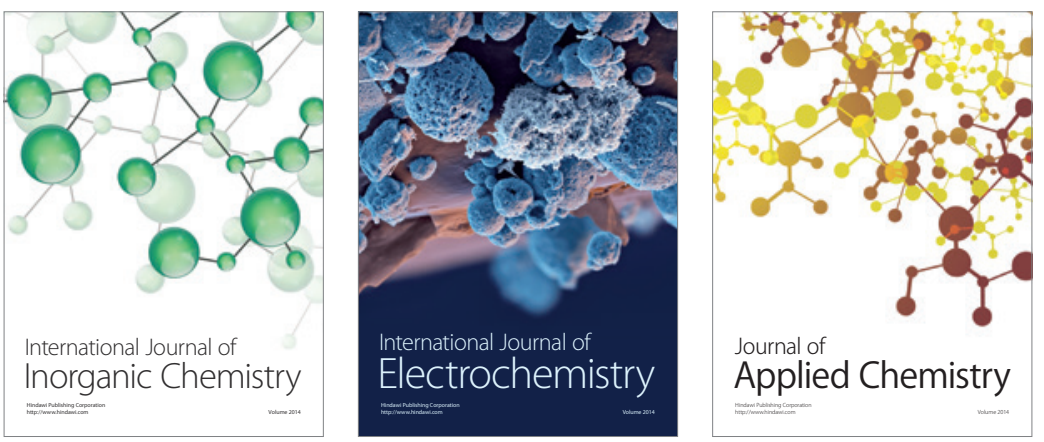

Journal of

Applied Chemistry
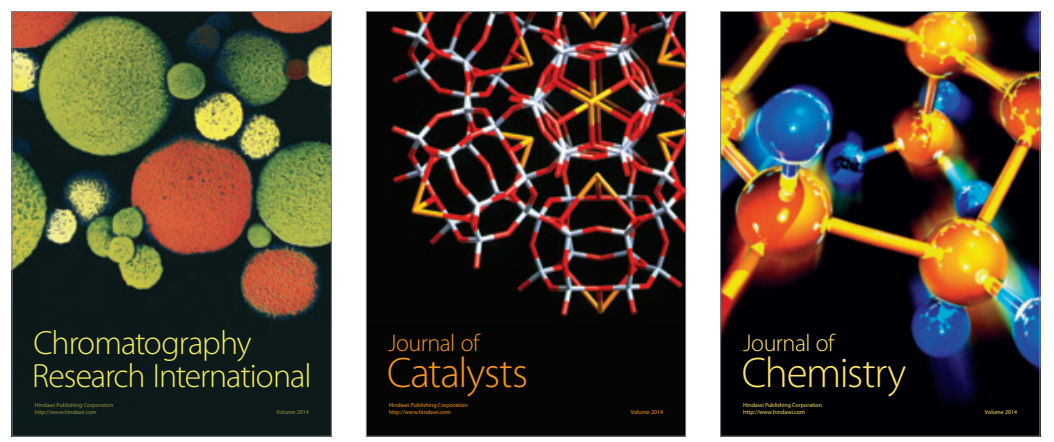
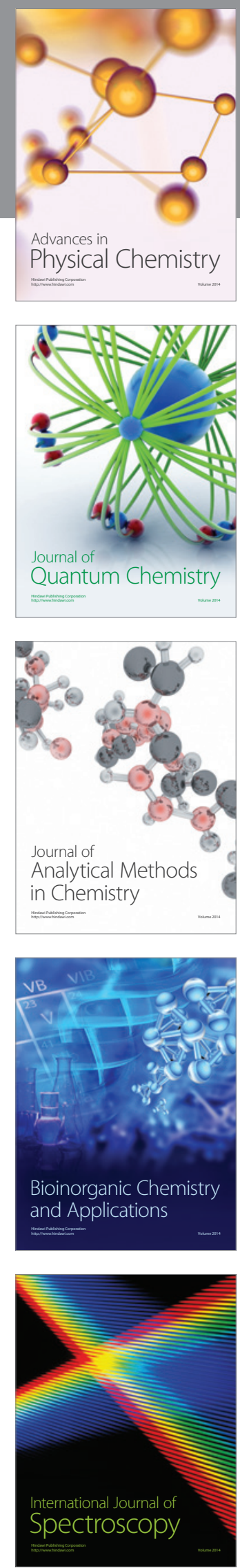